\title{
Thermal oxidative degradation of wood modified with aminophenylborates
}

\author{
Olga Klyachenkova ${ }^{1}$, Irina Stepina ${ }^{1, *}$ \\ ${ }^{1}$ Moscow State University of Civil Engineering, Department of General Chemistry, Yaroslavskoye \\ sh. 26, 129337 Moscow, Russia.
}

\begin{abstract}
Comparative thermal analysis in the presence of oxygen was carried out for samples of native pine wood and wood samples modified with aminophenylborates. Significant decrease in the amount of heat released during thermal decomposition of the modified samples was established, which is due to the increase of carbonaceous residues on the surface. Reduction of heat release during decomposition of the modified samples may be explained by the lower yield of combustible volatile products as well as by thin film of boron oxide, formed on the surface of the modified wood, that partially reflects heat flow. Produced upon the modifier decomposition water vapor and inert nitrogen oxides dilute gaseous mixture near the wood surface and isolate it from oxygen. This enhances fire-resistance of wood modified with mono- and diethanolamine $(\mathrm{N} \rightarrow \mathrm{B})$ phenylborates. Hydroxyl group at the sixth carbon atom of the glucopyranose ring of cellulose participates in reactions of cellulose modification, which prevents formation of flammable levoglucosan and, consequently, improves the fire-resistance of the modified wood.
\end{abstract}

\section{Introduction}

It has been shown in the previous studies that treatment of the wood surface with protective compositions based on aminophenylborates and water [1] ensures wood fire-retardant efficiency of group II (GOST R 53295-2009 ) [2]. High activity level of such modifiers should be noted - no more than $10 \%$ concentration of the modifiers provide the same protection level as $50 \%$ concentrations of aminoborate-based modifiers. There is obviously an effect of phenyl radical, present in the modifier composition, on fire-retardant efficiency of the modifier. It has earlier been found $[3,4]$ that polymers with a high content of phenyl groups are nonflammable.

Wood modification was performed by soaking pine saw dust in aqueous solutions of mono- and diethanolamine $(\mathrm{N} \rightarrow \mathrm{B})$ phenylborates: $10 \%$ solution of monoethanolamine$(\mathrm{N} \rightarrow \mathrm{B})$ phenylborate (composition 1$), 5 \%$ solution of monoethanolamine$(\mathrm{N} \rightarrow \mathrm{B}$ )phenylborate (composition 2) and 5\% solution of diethanolamine$(\mathrm{N} \rightarrow \mathrm{B}$ )phenylborate (composition 3), under constant stirring for three hours, followed by

\footnotetext{
${ }^{*}$ Corresponding author: StepinaIV@mgsu.ru
} 
drying out to constant weight in the air. Thermal analysis was carried out after prolonged extraction with water and drying out. To analyze the process of thermal oxidative degradation of the modified wood, differential scanning calorimetry (DSC) and thermogravimetric analysis (TGA) were carried out using SDT Q600 thermal analyzer in dynamic mode of heating in the air (flow rate of $100 \mathrm{ml} / \mathrm{min}$ ) with a heating rate of 5,10 and $15^{\circ} \mathrm{C} / \mathrm{min}$. Thermal analyzer measures heat flow and weight changes accompanying energy transitions and reactions taking place in materials.

\section{Results and discussion}

Simultaneous calorimetry and thermogravimetric analysis of the same sample on the same device provides enhanced analysis productivity and allows to reduce experimental error. Plotting and processing of thermoanalytical curves were performed using TA Universal Analysis 2000 software. Temperature ranges of wood degradation, weight loss within temperature ranges defined $(\%)$, and heat flow maxima $(\mathrm{W} / \mathrm{g})$ were found based on the obtained thermoanalytical curves.

Three temperature ranges were defined for thermal degradation of wood in the air (table 1, figures 1-4). Evaporation of surface-adsorbed and capillary condensed water occurs in the first temperature interval $\left(30-150^{\circ} \mathrm{C}\right)$ [5]. Weight loss of pine wood samples is insignificant, approximately $4-7 \%$ (table 1). At this stage, chemical structure of wood remains practically unaffected and volatile products are not produced. Upon wood modification with mono- and diethanolamine $(\mathrm{N} \rightarrow \mathrm{B})$ phenylborates, the wood surface polarity grows, leading to formation of hydrogen bonds between polar amino and hydroxyl groups of the modifiers and water molecules and, consequently, stronger retention of water molecules on the surface of wood. In the first temperature interval at heating rates of 10 and $15^{\circ} \mathrm{C} / \mathrm{min}$, lower weight loss values are characteristic to the wood samples modified with composition 3 as compared to the unmodified wood. This trend is also observed for the samples modified with composition 1 at $10^{\circ} \mathrm{C} / \mathrm{min}$ heating rate (figures $1-4$, table 1 ). This may be explained by higher energy costs required for breaking of hydrogen bonds [6].

However, weight loss of all modified samples at $5^{\circ} \mathrm{C} / \mathrm{min}$ heating rate and weight loss of wood samples modified with composition 2 at all three heating rates exceed weight loss of native wood samples (figures 1-4, table 1). In this case, presumably, part of energy is expended on wood polysaccharides dehydration, and protolytic -OH-groups on the surface of the modified wood catalyze this process.

In the second temperature range $\left(150-430^{\circ} \mathrm{C}\right)$, wood thermal degradation accompanied by formation of low molecular weight products and carbonaceous residues takes place. Reactions proceeding upon heating of wood to $270-280^{\circ} \mathrm{C}$ are endothermic and require energy. Upon further heating, endothermic process proceeds to exothermic process [7] characterized by reactions of thermal degradation of wood polymers, large amount of heat released, formation of liquid and gaseous decomposition products (carbon oxides, other non-condensable gases, acetic acid, methanol, tars). Charcoal is formed as a remainder of wood thermal degradation [8]. 
Table 1. Characteristics of TGA and DSC curves.

\begin{tabular}{|c|c|c|c|c|c|c|c|c|c|c|c|c|}
\hline & \multicolumn{12}{|c|}{ Heating rate, ${ }^{\circ} \mathrm{C} / \mathrm{min}$} \\
\hline & \multicolumn{3}{|c|}{ native wood } & \multicolumn{3}{|c|}{$\begin{array}{c}\text { wood + } \\
\text { composition } 1\end{array}$} & \multicolumn{3}{|c|}{$\begin{array}{c}\text { wood }+ \\
\text { composition } 2\end{array}$} & \multicolumn{3}{|c|}{$\begin{array}{c}\text { wood }+ \\
\text { composition } 3\end{array}$} \\
\hline & 5 & 10 & 15 & 5 & 10 & 15 & 5 & 10 & 15 & 5 & 10 & 15 \\
\hline $\begin{array}{c}\text { Temp } \\
\text { eratur } \\
\text { e } \\
\text { range } \\
\text { of } \\
\text { degrad } \\
\text { ation, } \\
{ }^{\circ} \mathrm{C} \\
\end{array}$ & $\begin{array}{l}30- \\
150\end{array}$ & $\begin{array}{l}30- \\
150\end{array}$ & $\begin{array}{l}30- \\
150\end{array}$ & $\begin{array}{l}30- \\
150\end{array}$ & $\begin{array}{l}30- \\
150\end{array}$ & $\begin{array}{l}30- \\
150\end{array}$ & $\begin{array}{l}30- \\
150\end{array}$ & $\begin{array}{l}30- \\
150\end{array}$ & $\begin{array}{l}30- \\
150\end{array}$ & $\begin{array}{l}30- \\
150\end{array}$ & $\begin{array}{l}30- \\
150\end{array}$ & $\begin{array}{l}30- \\
150\end{array}$ \\
\hline $\begin{array}{c}\text { Weigh } \\
\text { tloss } \\
\text { in the } \\
\text { range, } \\
\%\end{array}$ & 5.98 & $\begin{array}{c}6.1 \\
6\end{array}$ & 5.78 & 7.82 & 3.62 & 6.60 & 6.52 & 6.54 & 5.92 & 6.30 & 4.44 & $\begin{array}{c}4.9 \\
1\end{array}$ \\
\hline $\begin{array}{c}\text { Temp } \\
\text { eratur } \\
\text { e } \\
\text { range } \\
\text { of } \\
\text { degrad } \\
\text { ation, } \\
{ }^{\circ} \mathrm{C}\end{array}$ & $\begin{array}{c}150 \\
- \\
380\end{array}$ & $\begin{array}{c}150 \\
- \\
380\end{array}$ & $\begin{array}{l}150- \\
400\end{array}$ & $\begin{array}{l}150- \\
410\end{array}$ & $\begin{array}{l}150- \\
420\end{array}$ & $\begin{array}{l}150- \\
430\end{array}$ & $\begin{array}{l}150- \\
410\end{array}$ & $\begin{array}{l}150- \\
420\end{array}$ & $\begin{array}{l}150- \\
430\end{array}$ & $\begin{array}{l}150- \\
400\end{array}$ & $\begin{array}{l}150- \\
420\end{array}$ & $\begin{array}{c}150 \\
- \\
430\end{array}$ \\
\hline $\begin{array}{c}\text { Weigh } \\
\mathrm{t} \text { loss } \\
\text { in the } \\
\text { range, } \\
\%\end{array}$ & $\begin{array}{c}69.9 \\
1\end{array}$ & $\begin{array}{c}70 \\
49\end{array}$ & $\begin{array}{c}72.7 \\
1\end{array}$ & $\begin{array}{c}59.3 \\
4\end{array}$ & $\begin{array}{c}60.9 \\
3\end{array}$ & $\begin{array}{c}59.1 \\
6\end{array}$ & $\begin{array}{c}62.4 \\
5\end{array}$ & $\begin{array}{c}61.6 \\
0\end{array}$ & $\begin{array}{c}61.9 \\
9\end{array}$ & $\begin{array}{c}63.1 \\
7\end{array}$ & $\begin{array}{c}65.1 \\
6\end{array}$ & $\begin{array}{c}65 . \\
59\end{array}$ \\
\hline $\begin{array}{l}\text { Heat } \\
\text { flow } \\
\text { maxi } \\
\text { mum, } \\
\text { W/g }\end{array}$ & 4.31 & $\begin{array}{c}8.5 \\
2\end{array}$ & $\begin{array}{c}10.1 \\
5\end{array}$ & 2.21 & 3.94 & 4.94 & 2.67 & 4.65 & 6.07 & 3.11 & 5.57 & $\begin{array}{c}7.5 \\
3\end{array}$ \\
\hline $\begin{array}{c}\text { Temp } \\
\text { eratur } \\
\text { e } \\
\text { range } \\
\text { of } \\
\text { degrad } \\
\text { ation, } \\
{ }^{\circ} \mathrm{C}\end{array}$ & $\begin{array}{c}380 \\
- \\
470\end{array}$ & $\begin{array}{c}380 \\
- \\
470\end{array}$ & $\begin{array}{l}400- \\
480\end{array}$ & $\begin{array}{l}410- \\
650\end{array}$ & $\begin{array}{l}420- \\
670\end{array}$ & $\begin{array}{l}430- \\
700\end{array}$ & $\begin{array}{l}410- \\
650\end{array}$ & $\begin{array}{r}420- \\
670\end{array}$ & $\begin{array}{l}430- \\
700\end{array}$ & $\begin{array}{l}400- \\
650\end{array}$ & $\begin{array}{c}420- \\
650\end{array}$ & $\begin{array}{c}430 \\
- \\
650\end{array}$ \\
\hline $\begin{array}{c}\text { Weigh } \\
\mathrm{t} \text { loss } \\
\text { in the } \\
\text { range, } \\
\%\end{array}$ & $\begin{array}{c}23.7 \\
3\end{array}$ & $\begin{array}{l}23 . \\
62\end{array}$ & $\begin{array}{c}21.4 \\
8\end{array}$ & $\begin{array}{c}24.1 \\
3\end{array}$ & $\begin{array}{c}24.8 \\
0\end{array}$ & $\begin{array}{c}23.7 \\
8\end{array}$ & $\begin{array}{c}25.2 \\
3\end{array}$ & $\begin{array}{c}25.0 \\
6\end{array}$ & $\begin{array}{c}24.9 \\
4\end{array}$ & $\begin{array}{c}28.0 \\
7\end{array}$ & $\begin{array}{c}26.8 \\
3\end{array}$ & $\begin{array}{r}25 \\
11\end{array}$ \\
\hline $\begin{array}{l}\text { Heat } \\
\text { flow } \\
\text { maxi } \\
\text { mum, } \\
\text { W/g }\end{array}$ & $\begin{array}{c}10.2 \\
4\end{array}$ & $\begin{array}{l}12 \\
23\end{array}$ & $\begin{array}{c}13.2 \\
4\end{array}$ & 0.74 & 1.70 & 2.83 & 0.81 & 2.92 & 3.85 & 1.15 & 2.99 & $\begin{array}{c}4.6 \\
1\end{array}$ \\
\hline
\end{tabular}




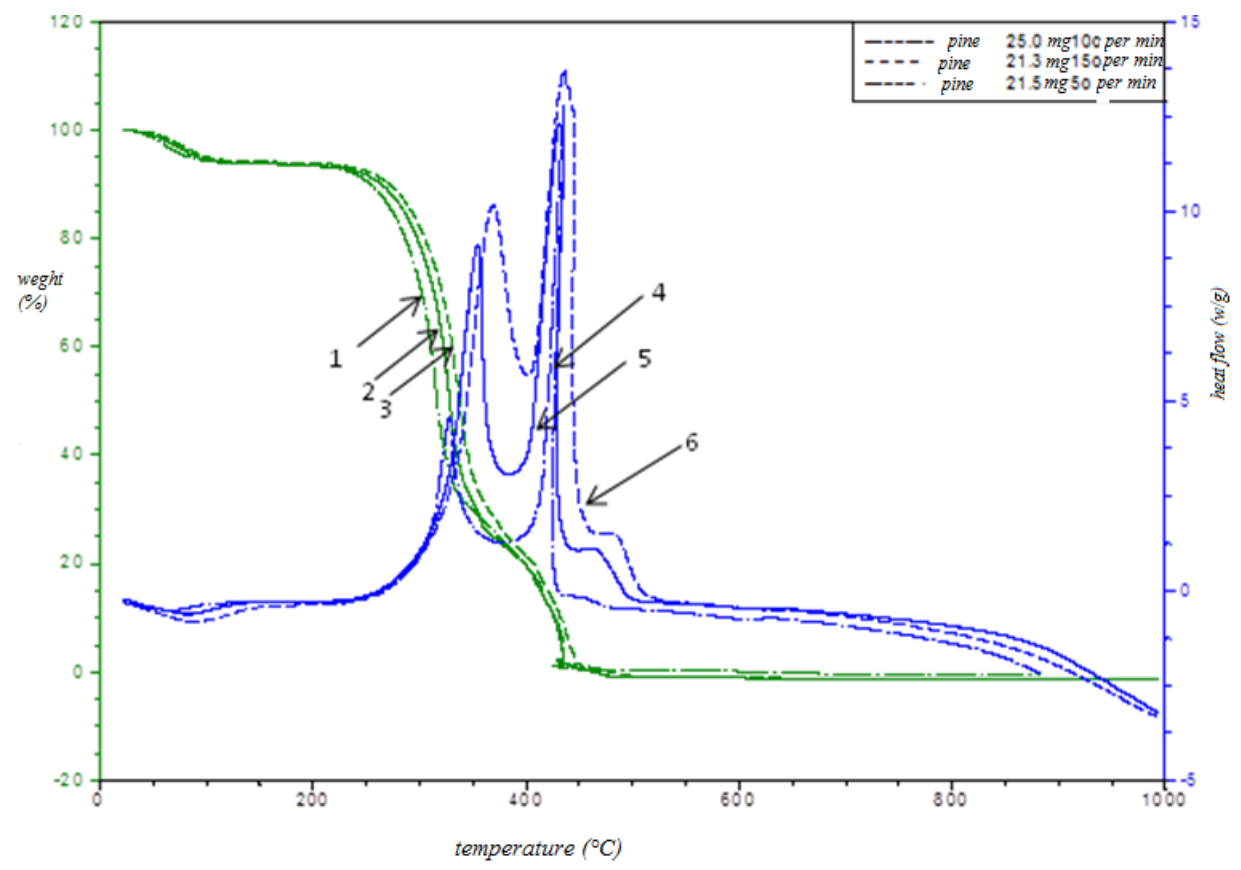

Fig. 1. TGA $(1,2,3)$ and $\operatorname{DSC}(4,5,6)$ curves for the native wood samples $(1,4$ - heating rate $5^{\circ} \mathrm{C} / \mathrm{min} ; 2,5$ - heating rate $10^{\circ} \mathrm{C} / \mathrm{min} ; 3,6$ - heating rate $15^{\circ} \mathrm{C} / \mathrm{min}$ ).

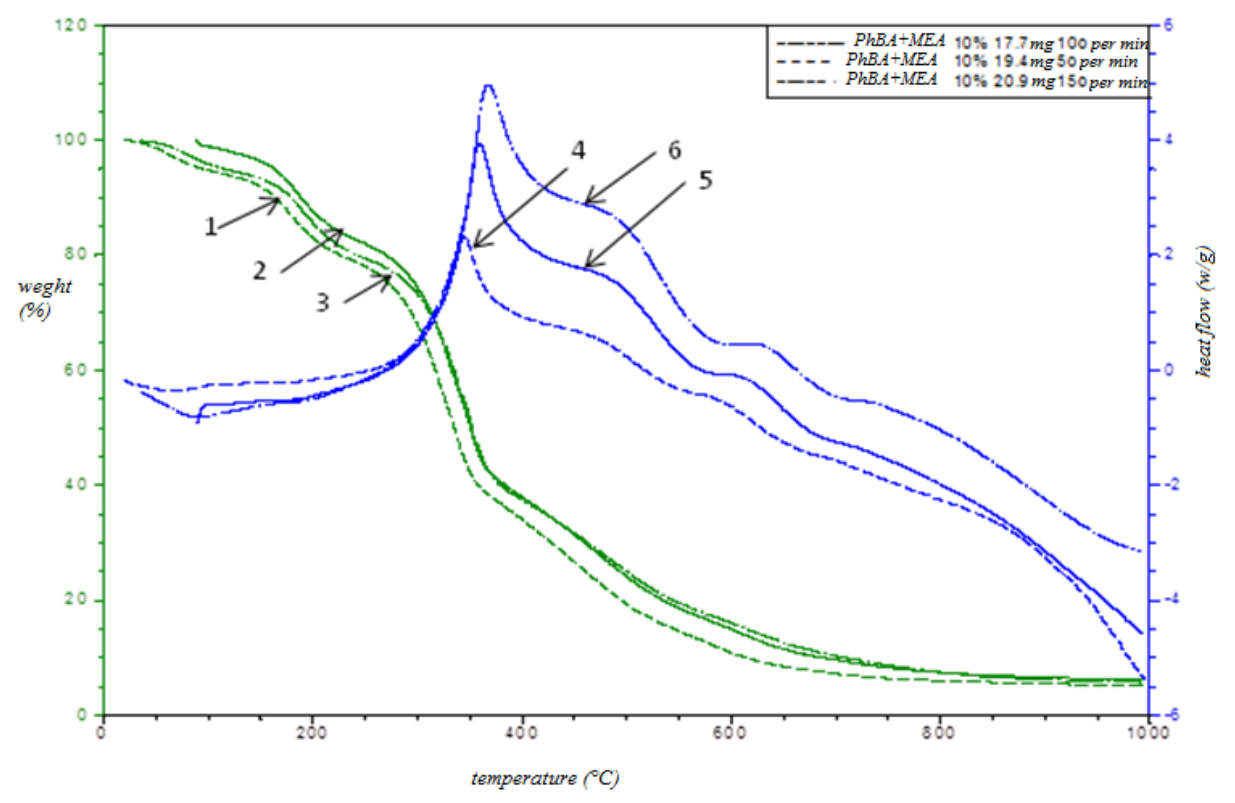

Fig. 2. TGA $(1,2,3)$ and DSC $(4,5,6)$ curves for the wood samples modified with composition $1(1$, 4 - heating rate $5^{\circ} \mathrm{C} / \mathrm{min} ; 2,5$ - heating rate $10^{\circ} \mathrm{C} / \mathrm{min} ; 3,6$ - heating rate $15^{\circ} \mathrm{C} / \mathrm{min}$ ). 


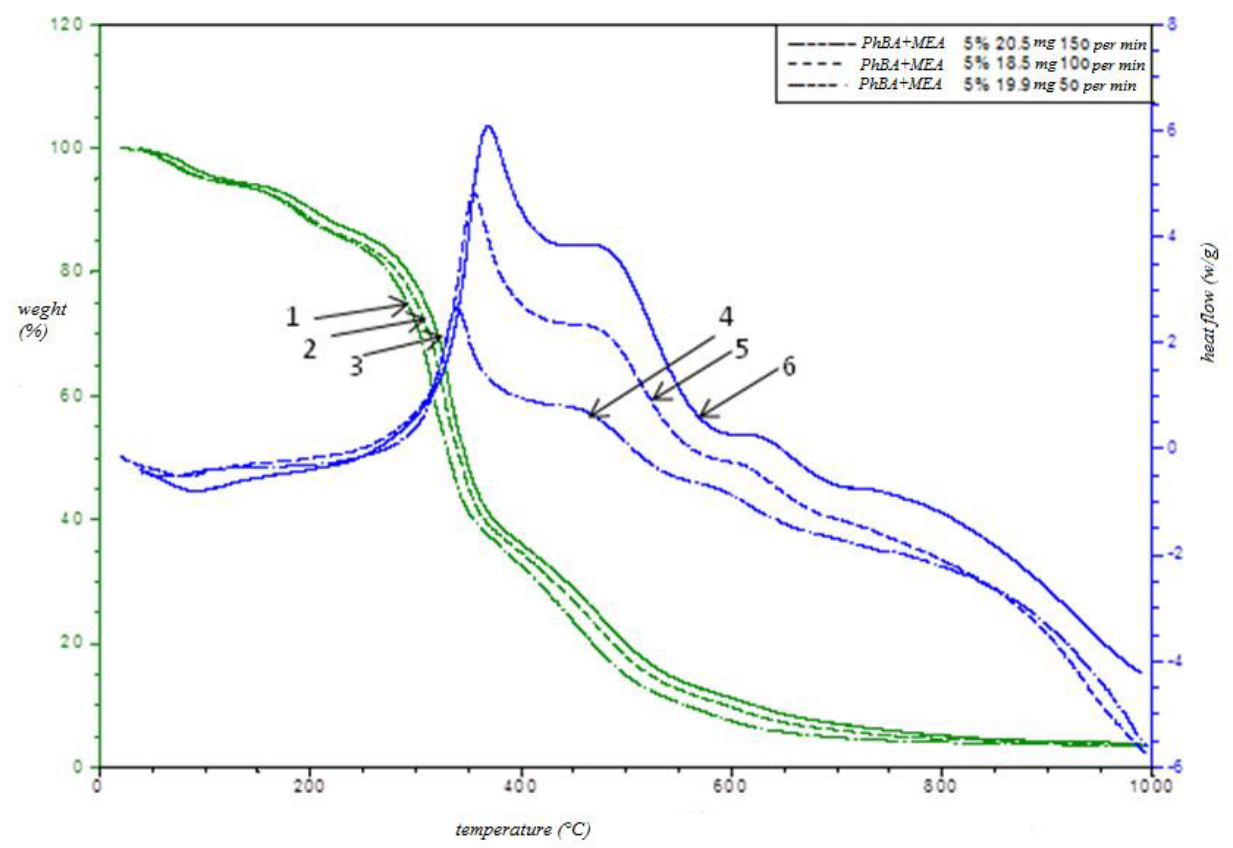

Fig. 3. TGA $(1,2,3)$ and DSC $(4,5,6)$ curves for the wood samples modified with composition $2(1$, 4 - heating rate $5^{\circ} \mathrm{C} / \mathrm{min} ; 2,5$ - heating rate $10^{\circ} \mathrm{C} / \mathrm{min} ; 3,6$ - heating rate $15^{\circ} \mathrm{C} / \mathrm{min}$ ).

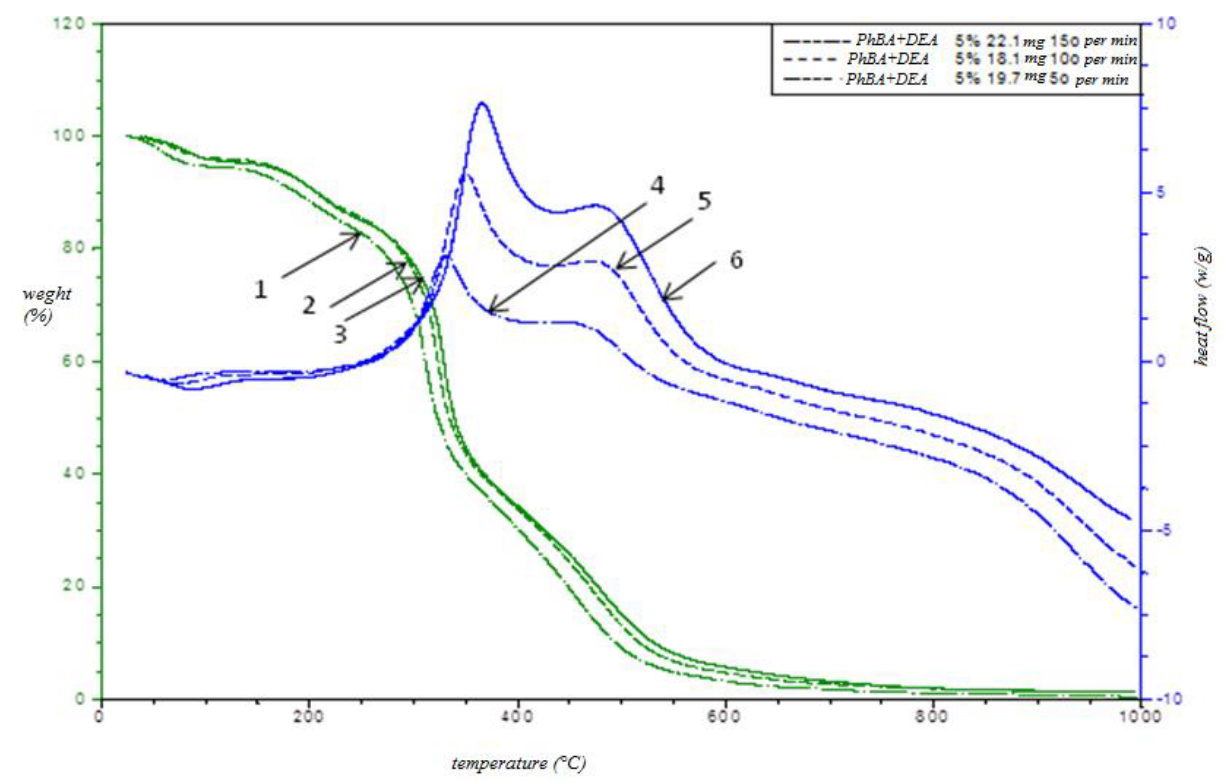

Fig.4. TGA $(1,2,3)$ and DSC $(4,5,6)$ curves of the wood samples modified with composition $3(1,4$ - heating rate $5^{\circ} \mathrm{C} / \mathrm{min} ; 2,5$ - heating rate $10^{\circ} \mathrm{C} / \mathrm{min} ; 3,6$ - heating rate $15^{\circ} \mathrm{C} / \mathrm{min}$ ).

The second temperature range accounts for weight loss of approximately $70-73 \%$ for the unmodified wood samples. Heating rate increase causes increase of the weight loss value for the unmodified wood samples and the wood samples modified with composition 3 (table 1). Noteworthy, weight loss in this temperature range is notably reduced for wood samples modified with solutions of mono- and diethanolamine $(\mathrm{N} \rightarrow \mathrm{B})$ phenylborates 
compared to the unmodified sample: $5-7 \%$ for the samples modified with composition 3, 7$10 \%$ for the samples modified with composition 2 , and $10-13 \%$ for the samples modified with composition 1 (table 1). Modification with solutions of mono- and diethanolamine $(\mathrm{N} \rightarrow \mathrm{B})$ phenylborates changes the scenario of wood thermal decomposition. For the modified samples, heat release temperature maxima of DSC curves corresponding to exothermic reactions of thermal degradation of wood polymers and to production of low molecular weight compounds are shifted to higher temperatures area. This impedes the degradation process at the main stage of wood thermal decomposition and enhances fireresistance of wood (figures 1-4) [9]. Wood modification with solutions of mono- and diethanolamine $(\mathrm{N} \rightarrow \mathrm{B})$ phenylborates also leads to $1.5-2$-fold decrease of heat released at the main stage of thermal oxidative degradation of wood (table 1, figures 1-4). The lowest heat flow maximum is observed upon wood modification with composition 1 at the highest concentration of the modifier (figure 2). Reduced heat release during decomposition of the modified samples may be explained by the lower yield of combustible volatile products [10] as well as by thin film of boron oxide, formed on the surface of the modified wood, that partially reflects heat flow [11]. Formed upon a modifier decomposition water vapor and inert nitrogen oxides dilute gas mixture near the wood surface and isolate it from oxygen [11]. During thermal depolymerization of cellulose, flammable levoglucosan (1,6anhydro- $\beta$-D-glucopyranose) is formed as an intermediate product, at a yield of about 10 $13 \%$ [8]. Hydroxyl group at the sixth carbon atom of the cellulose glucopyranose ring participates in modification reactions of cellulose, which prevents the formation of levoglucosan and, consequently, enhances fire-resistance of the modified wood [8].

Oxidation of carbonaceous residues takes place in the third temperature range (380$700^{\circ} \mathrm{C}$ ). Modification of wood samples with compositions containing mono- and diethanolamine $(\mathrm{N} \rightarrow \mathrm{B})$ phenylborates leads to significant changes of DSC curve. In contrast to the unmodified samples, heat flow gradually declines with temperature increase during transition from exothermic processes of thermal degradation of wood polymers to oxidation of carbonaceous residues (figures 1-4). Small peak is observed in the DSC curve for the samples modified with composition 3 , at that amount of heat is reduced almost 3 folds at a heating rate of $15^{\circ} \mathrm{C} / \mathrm{min}$ and 9 folds at a heating rate of $5^{\circ} \mathrm{C} / \mathrm{min}$. It should be noted that heat flow increases when heating rate increases both for the control and for the modified samples (table 1). Moreover at this stage, heat release maxima for the samples modified with composition 3 are shifted to higher temperatures as compared to the native wood sample. In this case, shift of heat release maxima is 10,40 and $30^{\circ} \mathrm{C}$ at heating rates of 5 , 10 and $15^{\circ} \mathrm{C} / \mathrm{min}$, respectively (figures 1,4 ). This points to higher thermal stability of carbonaceous residues resulting from thermal degradation of the modified wood. Greater decrease of heat effect of the process in the third temperature range is characteristic to the samples modified with compositions 2 and 3 (figures 2 and 3), there are no peaks in DSC curves in the range of carbonaceous residues oxidation.

\section{Conclusion}

Significant heat reduction is due to increase of carbonaceous residues on the surface of the modified samples, which provides thermal insulation and partially reflects heat flow as well as prevents the formation of volatile wood combustion products. It enhances fireresistance of wood modified with mono- and diethanolamine $(\mathrm{N} \rightarrow \mathrm{B})$ phenylborates. 


\section{References}

1. I.V. Stepina, O.A. Kolesnikova, Flame-retardant composition APhB Patent RUS 255269122.04 .2014 (2014)

2. I.V. Stepina, O.A. Klyachenkova, Nauch. oboz. 12, 79-82 (2013)

3. V.I. Kodolov, Flame retardants for polymer materials (Khimia, Moscow, 1980)

4. Yu.A. Mihailin, Thermostable polymers and polymeric materials (Professiya, SaintPetersburg, 2006)

5. Ye.N. Pokrovskaya, I.I. Pishchik, N.V. Smirnov, Yu.K. Naganovskiy, Stroit. Mat. 9, 34-35 (2000)

6. V.I. Kondrat'yev, A.N. Zakazov, N.A. Krasikova, E.I. Chupka, Khimiya drevesiny 5, 90-94 (1987)

7. R.Sh. Yenaleyev, F.M. Gimranov, A.V. Kargin, R.Z. Khayrullin, Yu.S. Chistov, Vestnik tekh. univ. 18(12), 74-77 (2015)

8. V.I. Azarov, A.V. Burov, A.V. Obolenskaya, Chemistry of wood and synthetic polymers: a textbook for high schools (SPbLTA, Saint-Petersburg, 1999)

9. D.M. Nigmatullina, A.B. Sivenkov, Internet-journal «Tekhnologii tekhnosfernoy bezopasnosti» 3(61), 108-115 (2015)

10. N.I. Akinin, N.O. Melnikov, S.A. Maksimenko, Vektor nauki TGU 3, 28-31 (2013)

11. A.A. Leonovich, Fire protection of wood and wood materials: tutorial (LTA, SaintPetersburg, 1994) 